\section{UN ANÁLISIS COMPARADO SOBRE LA IMPLEMENTACIÓN DE POLÍTICAS DE REGULARIZACIÓN \\ DE ASENTAMIENTOS INFORMALES EN ARGENTINA, BRASIL Y MÉXICO ${ }^{1}$}

María Mercedes Di Virgilio², Tomás Alejandro Guevara $^{3}$, María Soledad Arqueros ${ }^{4}$

\section{Resumen}

En este trabajo se abordan las políticas públicas de regularización dominial y urbanística implementadas en América Latina en las últimas décadas, haciendo hincapié en la experiencia comparativa de tres países de la región: Argentina, Brasil y México. Para ello, se hace una breve reseña del desarrollo del hábitat informal y de la situación habitacional de los países seleccionados. Posteriormente, se analizan la normativa urbana vigente, las políticas de regularización dominial y urbanística implementadas a nivel federal y los diferentes organismos involucrados. Finalmente, se contraponen los diferentes modelos de gestión y articulación interjurisdiccional existentes en cada uno de los países. El análisis se vale de estadísticas oficiales

\section{A COMPARATIVE ANALYSIS OF THE IMPLEMENTATION OF REGULATORY POLICIES OF INFORMAL SETTLEMENTS IN ARGENTINA, BRAZIL AND MEXICO'}

\author{
María Mercedes Di Virgilio², Tomás Alejandro \\ Guevara $^{3}$, María Soledad Arqueros ${ }^{4}$
}

\section{Abstract}

This paper addresses the different land-title and urban regulatory policies implemented in Latin America over the last decades, with a focus on the comparative experience of three countries of the region: Argentina, Brazil and Mexico. To this end, this contribution offers a brief overview of the development of informal habitat and the housing situation of the aforementioned countries. Then, current urban regulations as well as federal landtitle and urban regulatory policies and the different entities involved in such a process are analyzed. Finally, this paper provides a comparison of the different interjurisdictional management and linking models of each country. The analysis offered in this research uses official statistics and secondary 
y datos secundarios sobre condiciones habitacionales, normativas urbanas y programas vigentes. Pese a compartir la organización política federal, el análisis comparativo muestra grandes diferencias entre los países en función de los arreglos institucionales y la relación con el tipo de régimen de propiedad vigente.

\section{PALABRAS CLAVES: HÁBITAT - ORDENAMIENTO URBANO - POLÍTICAS DE REGULARIZACIÓN}

Fecha de recepción: 11.04.2013

Fecha de aceptación: 17.01.2014

1 Este trabajo se elaboró en el marco del proyecto de investigación "The rehabilitation of consolidated irregular settlements in Latin American Cities: Towards a "third generation" of public policy analysis and development" (2009-2012). Proyecto del Latin American Housing Network, Universidad de Texas en Austin y del Área de Estudios Urbanos del Instituto de Investigaciones Gino Germani, Facultad de Ciencias Sociales, Universidad de Buenos Aires. Dirección general del proyecto, Ph.D. Peter Ward; dirección del nodo Argentina, Dra. Mercedes Di Virgilio.

2 Argentina. Socióloga y Doctora en Ciencias Sociales por la Universidad de Buenos Aires. Investigadora adjunta del CONICET y del Instituto Gino Germani de la Facultad de Ciencias Sociales de la Universidad de Buenos Aires. Correo electrónico: mercedes. divirgilio@gmail.com

3 Argentina. Sociólogo, Magíster en Políticas Sociales y Doctor en Ciencias Sociales por la Universidad de Buenos Aires. Becario Postdoctoral del Consejo Nacional de Investigaciones Científicas y Técnicas, con sede en el Departamento de Ciencias Económicas y de la Administración, Sede Andina, Universidad de Río Negro.Correo electrónico: tomasguevara82@gmail.com

4 Argentina. Socióloga, Universidad de Buenos Aires. Candidata al Doctorado en Ciencias Sociales de la misma Universidad y becaria doctoral del CONICET con sede en Instituto de Investigaciones Gino Germani, Facultad de Ciencias Sociales, Universidad de Buenos Aires. Correo electrónico: soledad.arqueros@gmail.com data on housing conditions, urban regulations and programs currently in force. Although sharing the same federal political organization, the comparative analysis shows considerable differences among the three studied countries regarding institutional structure and the relationship with their respective current property regimes.

\section{KEYWORDS: HABITAT - URBAN PLANNING - REGULATORY POLICIES}

\author{
Received: 11.04.2013 \\ Accepted: 17.01.2014
}

1 This paper was elaborated within the framework of the research project "The Rehabilitation of Consolidated Irregular Settlements in Latin American Cities: Towards a 'Third Generation' of Public Policy Analysis and Development" (2009-2012). Latin American Housing Network Project. The University of Texas at Austin and the Urban Studies Area at the Gino Germani Research Center, Faculty of Social Sciences, University of Buenos Aires. Director-general of the project: Peter Ward, PhD; director of the Argentinian phase of the project: Mercedes di Virgilio, $\mathrm{PhD}$.

2 Argentina. Sociologist, $\mathrm{PhD}$ in Social Sciences, University of Buenos Aires.Assistant researcher at CONICET and the Gino Germani Institute, Faculty of Social Sciences, University of Buenos Aires. Email:divirgilio@gmail.com

3 Argentina. Sociologist, MA in Social Policies, PhD in Social Sciences, University of Buenos Aires. Postdoctoral fellow at the National Council of Scientific and Technical Research, Department of Economic and Administrative Sciences, Andean Campus, University of Rio Negro. Email: tomasguevara82@ gmail.com

4 Argentina. Sociologist, University of Buenos Aires.Doctoral candidate in Social Sciences, University of Buenos Aires. Doctoral fellow at CONICET, Gino Germani Research Institute, Faculty of Social Sciences, University of Buenos Aires. Email: soledad. arqueros@gmail.com 


\section{Introducción}

En términos generales, se puede afirmar que una importante proporción de la población de las ciudades latinoamericanas resuelve sus necesidades habitacionales por fuera de los mecanismos del mercado inmobiliario formal. Si bien el Estado ha apelado a la construcción de vivienda social como estrategia para ampliar el acceso a la vivienda, no ha conseguido dar respuesta a las necesidades de vivienda de la población de menores recursos. De esta manera, amplios sectores se han visto obligados a desarrollar estrategias propias de acceso al suelo y la vivienda, dando origen a las urbanizaciones informales. En general, los barrios resultantes de este proceso se caracterizan por la precariedad que presentan en sus condiciones habitacionales. Ante este panorama, el Estado fue implementando políticas de regularización dominial y urbanística para mejorar las condiciones de hábitat de estos barrios e integrar a sus habitantes al régimen de propiedad. El presente trabajo tiene por objeto indagar acerca del diseño y la implementación de estas políticas de regularización en las últimas décadas, sus alcances y limitaciones, en Argentina, Brasil y México. La selección de los países está vinculada a la trayectoria de investigación compartida con investigadores de esos países en el marco de la Latin American Housing Network. El período de análisis escogido está relacionado, en primer lugar, con el surgimiento de este tipo de

\section{Introduction}

In general terms, it can be said that a large proportion of the population living in Latin American cities find solutions to their housing needs in mechanisms other than those provided bythe formal housing market. However, although the State has appealed to the construction of social housing as a strategy to expand the access to housing, it has failed to respond to the housing needs of low-income people. In that way, large segments of the population have been forced to develop their own access strategies to land and housing, thus giving rise to informal settlements. In general, the resulting neighborhoods are characterized by poor housing conditions. Against this backdrop, the State implemented land-title and urban regulatory policies, in order to improve the housing conditions of these neighborhoods and integrate their residents into the property regime. The aim of this paper is to look into the design and implementation as well as into the scope and limitations of these regulatory policies over the last decades in Argentina, Brazil and Mexico. The choice of countries is related to the shared research track among researchers of these countries in the framework of the Latin American Housing Network. The analysis period is related, in the first place, to the emergence of this type of policies in the region over the period spanning 
políticas en la región durante la década de 1960 1970 y, en segundo lugar, su difusión y masificación a partir de la década de 1990.

En la primera sección del trabajo se caracteriza conceptualmente el desarrollo del hábitat informal en la región especificando sus características. Posteriormente, se caracteriza brevemente la situación habitacional en los tres países seleccionados, haciendo hincapié en la extensión que presentan las tipologías de hábitat informal. Luego, se analizan las políticas de regularización implementadas en los países seleccionados y los instrumentos utilizados en su implementación. Finalmente, se trazan algunos ejes comparativos que surgen del análisis de los modelos de gestión y las modalidades de articulación interjurisdiccionales.

\section{Hábitat informal y condiciones habitacionales en América Latina}

Como se dijo en la introducción, gran parte de la población de América Latina resuelve sus necesidades por fuera del mercado inmobiliario formal. No obstante, esto no quiere decir que estén excluidos de la dinámica de producción capitalista del hábitat, sino que se mueven en los circuitos del hábitat informal.

Asumir la existencia de los circuitos del hábitat informal no implica adherir a una taxonomía
1960-1970 and, in the second place, to their dissemination and expansion from 1990 onwards.

In the first part of this research, the development of informal habitat in the region is conceptually determined by way of the specification of its characteristics. Subsequently, the housing situation in these three selectedcountries is briefly detailed with a focus on the extension of informal habitat typologies. Then, this paper analyzes the regulatory policies implemented in these countries and the instruments used in such a process. Finally, this contribution provides some comparisons derived from the analysis of management models and interjurisdictional linking methods.

\section{Informal Habitat and Housing Conditions in Latin America}

As stated in the introduction, a large proportion of the Latin American population find a solution to their needs outside the formal housing market. However, this does not mean that they are excluded from the dynamics of the capitalist production of habitat, but rather they move around the circuits of informal habitat.

Assuming the existence of circuits of informal habitat does not imply the adherence to a dualist 
dualista sobre la existencia de un mercado formal versus otro informal. Al contrario, supone afirmar que la "informalidad es parte constituyente de la estructura productiva y territorial de la ciudad y que pone de manifiesto el carácter segmentado de un único mercado de trabajo y de tierra que refleja la heterogeneidad del sistema"s. En este sentido, existen acoplamientos e interrelaciones entre el sector informal y el formal, entre muchos otros: la provisión de insumos y capital, el trabajo asalariado, etc.

En términos generales, los procesos de producción del hábitat constituyen un universo heterogéneo de prácticas sociales de producción y reproducción de las condiciones sociales necesarias para habitar en la ciudad. Este universo incluye prácticas tan disímiles como la construcción a través de empresas constructoras o los procesos de autoconstrucción del hábitat. No obstante, nos interesa delimitar aquí lo que denominamos el hábitat informal.

Hábitat informal es un concepto que refiere a la situación de tenencia del lote y/o la vivienda (informalidad dominial) o bien está vinculada con las condiciones urbano-ambientales de desarrollo del hábitat (informalidad urbanística) ${ }^{6}$. Desde esta perspectiva, la informalidad se origina cuando la situación de tenencia o las condiciones urbanísticas no se ajustan a la normativa que regula las

5 Herzer, Di Virgilio, Rodríguez y Redondo, 2008.

6 Di Virgilio, Arqueros y Guevara, 2011. taxonomy about a confrontation between formal and informal markets. On the contrary, it means that "informality is a constituent of the productive and territorial structure of the city that reveals the segmented nature of a unique job and land market which, in turn, reflects the heterogeneity of the system". In this sense, there are couplings and interrelations between informal and formal sectors such as the provision of supplies and resources, paid employment, etc.

In general terms, habitat production processes constitute a varied universe of social practices of production and reproduction of the essential social conditions to live in the city. Such a universe includes disparate practices such as the construction of dwellings through building firms or self-help construction processes. However, it is in our interest to clarify the definition of informal habitat.

The concept of informal habitat refers either to land and/or housing tenure (informal landtitle) or the urban-environmental conditions for habitat development (urban informality) ${ }^{6}$. From this perspective, informality emerges when tenure or urban conditions do not adjust to the rules governing the access and occupation of land and

5 Herzer, Di Virgilio, Rodríguez and Redondo, 2008.

6 Di Virgilio, Arqueros and Guevara, 2001. 
relaciones de acceso y ocupación de la tierra y de la vivienda. Remite así, al orden jurídico que regula las relaciones sociales y que se expresan territorialmente en los patrones de localización residencial y en la situación habitacional predominantes entre diferentes sectores sociales. De esta manera, la informalidad se define por "la forma en que se resuelve la relación con el mercado de tierra y vivienda y con el sistema de propiedad"7.

No debe ser imputado mecánicamente a la noción de hábitat informal el carácter precario o deficitario en términos de las condiciones de vida de la población involucrada, sino que refiere a la relación de dichas condiciones con el orden jurídico imperante en un momento determinado. Por ello, la informalidad es inseparable de la intervención estatal reguladora: es ella quien fija la frontera entre la informalidad y la formalidad. Este límite es variable en el tiempo y expresa, como toda política pública, la correlación de fuerzas entre los diferentes actores involucrados ${ }^{8}$. La situación de tenencia da cuenta de la relación de determinados procesos de producción del hábitat con la normativa urbana vigente en un determinado momento histórico. En este sentido, la informalidad urbana está "mediada también por factores políticos y sociales, y por decisiones políticas que pueden orientar o bien facilitar procesos integrales de inserción urbana plena,

7 Herzer, Di Virgilio, Rodríguez y Redondo, 2008, p. 176.

8 Oszlak, 1991. housing. This leads us back to the legal provisions that regulate social relationships, the latter being territorially expressed in residential localization patterns and the predominant housing situation of different social segments. In this manner, informality is defined by "the way the relationship with the land and housing markets, as well as with the property system, is solved".

The poor or weak nature of the living conditions of the population involved should not be related to the notion of informal habitat, but rather should refer to the relationship between these conditions and the prevailing legal provisions at a specific period of time. For this reason, informality is inseparable from the regulatory intervention of the State, the latter fixing the boundaries between informality and formality. Such a limit varies over time and denotes, as in the case of all public policies, the correlation of forces among the different actors involved . $^{2}$ The situation of tenure reflects the relationship between certain habitat production processes with current urban regulations at a specific moment. In this sense, urban informality is "also mediated by political and social factors and political decisions that may guide or facilitate

7 Herzer, Di Virgilio, Rodríguez and Redondo, 2008, p. 176, 8 Oszlak, 1991. 
o bien pueden reproducir lógicas fragmentadas y fragmentarias".

Por lo dicho, no debe confundirse la noción de hábitat informal con la noción de hábitat popular, ya que son abordajes analíticos diferentes. La primera de estas nociones remite al ordenamiento jurídico vigente en un determinado momento histórico, mientras que la segunda remite a las diferentes manifestaciones del habitar por parte de los sectores populares de la región, es decir, a las relaciones entre las formas de habitar y la estructura social.

Es importante entonces no yuxtaponer estas nociones, porque se cae en el error de pensar que todo proceso de hábitat popular es informal. Tampoco se debe caer en el error de imputar a cualquier fenómeno de hábitat informal el carácter de popular. Asimismo, existen numerosas variantes en que la informalidad está puesta al servicio de los intereses de sectores sociales acomodados que se extralimitan en el uso y ocupación de espacios comunes, como también puede verse en Argentina en muchos casos de urbanizaciones cerradas donde se localizan sectores de ingresos medio-altos y altos.

Finalmente, la informalidad, tal como ha sido conceptualizada en este apartado, pone de relieve el acceso desigual que tienen los diferentes grupos

9 Herzer, Di Virgilio, Rodríguez y Redondo, 2008, p. 184. full urban insertion processes or reproduce fragmented and fragmentary logics"

Consequently, the notion of informal habitat should not be confused with that of formal habitat, as they are approached from different analytical perspectives. In this case, while the first of these notions refers to legal provisions prevailing at a specific moment in time, the second concept makes reference to the different inhabiting manifestations of low-income segments within the region, that is to say, the relationship between ways of inhabiting and the social structure.

It is important, then, not to juxtapose these two notions because it would be a mistake to label all popular habitat processes as informal. In the same vein, labeling all informal habitat processes as popular would be a mistake as well. There are also numerous variables in which informality serves the interest of well-off social groups that exceed the use and occupation of common spaces as in the case of Argentina, where gated communities concentrate mid-high and high segments.

Finally, according to the conceptualization presented in this section, the concept of informality underlines the inequitable access to the right

$9 \quad$ Herzer, Di Virgilio, Rodríguez and Redondo, 2008, p. 184. 
socioeconómicos al derecho a la ciudad ${ }^{10}$. En tal sentido, la política de suelo, deja el acceso al suelo y la vivienda sujeta a la capacidad de pago de las familias. Esto no sólo afecta la oportunidad de los hogares a una vivienda, sino también a las oportunidades asociadas a la localización. Así, los hogares habitan y viven la ciudad de manera desigual, lo cual repercute en las oportunidades de reproducción social que cada una de ellas tiene.

\section{Situación habitacional en los tres países seleccionados}

Los tres países seleccionados protagonizaron procesos de urbanización acelerados, vinculados principalmente a la reestructuración de las economías rurales por la modernización en el agro y por el desarrollo de procesos de industrialización por sustitución de importaciones desde las primeras décadas del siglo XX. Como la mayor parte de los países en la Región, concentran la mayor parte de la población en unas pocas grandes metrópolis. En este sentido, el caso de Argentina es el más extremo, con una situación de primacía urbana muy profunda por parte de Buenos Aires que multiplica varias veces la población de Rosario, la segunda ciudad en importancia del sistema urbano. Ambas ciudades concentran casi el $40 \%$ de la población

10 Lefebvre, 1969

24 revista invi № 80 / Mayo 2014 / Volumen № 29: 17-51 to the city ${ }^{10}$.In this sense, land policies grant access to land and housing to families who can afford to pay for them.This does not only affect the chances to purchase a home, but also hinders the opportunities related to the localization of housing. Thus, families inhabit and experience the city in an unequal fashion, which has a negative effect on their respective opportunities for social reproduction.

\section{The Housing Situation in the Three Selected Countries}

Since the first decades of the $X X$ century, the three selected countries experienced rapidurban development processes mainly linked to the restructuration of rural economies through the modernization of agriculture and the development of import-substitution methods.As with the majority of Latin American countries, these three states concentrate most of their population in a few metropolises. In this sense, Argentina presents the most extreme case, with Buenos Aires far exceeding the population of Rosario, the second largest city within the urban system. Both cities concentrate almost 40 percent of the total population. Then, to a lesser degree, the case of

10 Lefebvre, 1969. 
total. El caso Mexicano es menos acentuado, pero tiene la urbe más populosa de la región -el DF con algo más de 20 millones de personas-, junto con Guadalajara concentran casi el 22\% de la población total. Mientras, Brasil tiene un sistema urbano más equilibrado, con al menos dos metrópolis de gran tamaño (megalópolis, podría decirse): San Pablo con algo más de 19,5 millones y Rio de Janeiro con casi 12 millones -ambas concentran el $16,6 \%$ de la población total- y varias ciudades de gran tamaño. La literatura señala al desfasaje entre una industrialización incompleta e insuficiente y una urbanización acelerada como uno de los factores determinantes en el surgimiento de la informalidad y la pobreza urbana. Esta situación es particularmente notable en las grandes metrópolis de la región y está vinculada al carácter dependiente de las economías de la región ${ }^{11}$.

En este marco de extendida informalidad urbana, Argentina es uno de los pocos países que contó con un submercado de suelo urbano para sectores de bajos ingresos -los llamados loteos populares $^{12}$ - que debían su existencia a una normativa urbana muy laxa en términos de subdivisión y uso del suelo. Esta normativa autorizaba la subdivisión de fracciones de tierra en lotes individuales, en ocasiones sin mediar inversión en infraestructura

11 Vapñarsky y Gorojosky, 1986.

12 Clichevsky, 2006a.
Mexico shows that the Federal District (the most populated city of the region, with more than 20 million inhabitants) and Guadalajara account for 22 percent of the total population. As for Brazil, it is worth noting that its balanced urban system includes at least two large metropolises (megalopolises): São Paulo, with 19.5 million inhabitants and Rio de Janeiro, with 12 million inhabitants (both accounting for 16.6 percent of the total population) and other large cities. As the literature states, the gap between an incomplete and insufficient industrialization and a rapid urban development process is one of the key factors behind the emergence of urban informality and urban poverty. Such a situation can be particularly observed in the largest metropolises of the region and is related to the dependent nature of Latin American economies ${ }^{11}$.

Within this framework of extended urban informality, Argentina is one of the few countries that offered a sub-market for the provision of urban land to low-income groups (the so-called loteos populares ${ }^{12}$ ); such a market owed its existence to weak urban regulations in terms of subdivision and use of land. These regulations

\footnotetext{
11 Vapñarsky and Gorojosky, 1996.

12 Land sub-divisions providing small, affordable plots in settlements lacking basic infrastructure.
} 
o equipamiento alguno por parte de los loteadores, abaratando notablemente el costo de los terrenos. Esta política permitió un acceso masivo al suelo urbano para los sectores medios y medios-bajos. Asimismo, fue fuente de enormes beneficios para los loteadores que prácticamente con nula inversión multiplicaban el valor de los lotes por su incorporación al ejido urbano, primero, y después por la acción del Estado que proporcionaba la infraestructura y el equipamiento necesario para la consolidación de esos barrios ${ }^{13}$. Buena parte del acceso al suelo urbano desarrollado entre las décadas de 1940 y 1970 en los principales centros urbanos de Argentina se canalizó a través de estos mecanismos de loteos populares, que permitían la transferencia de suelo urbano sin servicios en mensualidades accesibles al ingreso medio de los asalariados, en un contexto de pleno empleo. Sin embargo, antes, durante y después de los loteos populares coexistieron con modalidades de hábitat informal que claramente estaban fuera de la formalidad sancionada en la normativa urbana: inquilinatos, villas de emergencia, asentamientos, ocupaciones de inmuebles, etc.

En Brasil, la falta de un submercado de suelo regulado generó informalidad tempranamente. Su expresión más cabal son las favelas que se extienden en la gran mayoría de los centros urbanos del país. En muchos casos, estas urbanizaciones son

13 Clichevsky, 1975. allowed the subdivision of land into individual plots, a process in which developers disregarded the use of infrastructure andamenities, thus reducing considerably the cost of land. This policy expanded the access of middle- and mid-low income segments of the population to urban land. Likewise, it was a source of great benefits for developers whotook advantage of the incorporation of these plots into the urban fabric and the State provision of infrastructure and amenities to multiply the value of land ${ }^{13}$. A good deal of the access to urban land over the 1940-1970 period in the main urban centers of Argentina was carried out by way of loteos populares, a procedure that allowed the transfer of land withoutany type of service in return of monthly payments deducted from the average wage of salaried workers, within a full employment context. However, the loteos populares coexisted with non-regulated informal habitat modalities such as tenancy, shanty towns, settlements, illegal occupation of property, etc.

In Brazil, the lack of a regulated land sub-market gave rise to informality at an early stage; the clearest example being the favelas that extend over most of Brazilian urban centers. In many cases, these settlements are the result of the informal occupation of land legally regarded as

13 Clichevsky, 1975. 
producto de la ocupación informal de tierras que eran consideradas legalmente como reservas y/o no urbanizables por motivos ambientales o topológicos, como es el caso de los morros, donde se construye en terrenos que superan la pendiente máxima habilitada para ser urbanizada, lo que genera recurrentes conflictos por el desprendimiento y deslizamiento del suelo.

El caso de México presenta especificidades notables porque cuenta con el antecedente de la Reforma Agraria, impulsada en el contexto de la Revolución Mexicana en la primera mitad del siglo XX. La informalidad estuvo vinculada fundamentalmente a las restricciones para incorporar las tierras rurales ejidales o comunales al desarrollo urbano y al accionar de loteadores piratas que daban cuenta de esta demanda por fuera de la legalidad imperante. Con el correr de las décadas, las tierras ejidales y comunales resultantes de dicha reforma fueron urbanizadas informalmente de forma masiva, ya por ocupación, loteos piratas o informales, dando origen a las colonias. Estas colonias son los principales destinatarios de los procesos de regularización que se analizan.

Existe una notable dificultad para cuantificar la población que vive en la informalidad, así como la población que ha sido atendida por políticas de regularización ${ }^{14}$. Más difícil aún es plantearse esta

14 Clichevsky, 2006a. non-developable reserves due to environmental or topological reasons; this is the case of the morros and the settlements built over these natural structures, which exceed the maximum slope for construction and generate conflicts as the result of landslides and land slippages.

The case of Mexico presents noteworthy specificities as it is preceded by the experience of the Land Reform, an initiative promoted within the context of the Mexican Revolution during the first half of the XX century. Here, informality was basically linked to the restrictions on the incorporation of ejido or communal lands into the urban development and the actions of illegal developers who operated outside the law. As decades went by, these ejido and communal lands resulting from such a reform were informally developed on a massive scale either by occupation or illegal/informal division of land, thus giving rise to the colonias. These colonias are the main recipients of these regulatory processes.

There is a great difficulty inquantifying the population living in informality and the population served by regulatory policies ${ }^{14}$. In this sense, it is even harder to suggest a comparative quantification among different countries due to

14 Clichevsky, 2006a. 
cuantificación a nivel comparado entre diferentes países, debido a la heterogeneidad de los indicadores; pese a lo cual intentamos una aproximación preliminar a través de la información oficial disponible por parte de los respectivos institutos de estadística de los países seleccionados.

Un indicador que puede servir para dar cuenta, en términos cuantitativos, de la extensión de la informalidad en los países seleccionados es el indicador de situación de tenencia de la vivienda relevado a través de los censos de población y vivienda. Un primer dato llamativo, es que el instituto mexicano no publica dicho dato, en un país donde se sabe que el conflicto por la tenencia de tierras ejidales y/o comunales y urbanas es uno de los principales factores de desarrollo de la informalidad urbana. Por su parte, en Argentina, la informalidad según este indicador asciende a $14,1 \%{ }^{15}$, mientras que en Brasil es del $9.9 \%^{16}$. Este indicador nos permite aproximarnos al universo que potencialmente podría ser sujeto de políticas de regularización dominial, en cada uno de los países. En tanto revela la condición de tenencia de la vivienda y el terreno por parte del hogar censado, por lo que es uno de los indicadores fundamentales para identificar el universo de informalidad dominial urbana. No

15 Los datos de Argentina corresponden al Censo 2010. Instituto Nacional de Estadísticas y Censos. www.indec.gov.ar.

16 Los datos de Brasil corresponden al Censo 2010. Instituto Brasileiro de Geografia y Estadística. www.ibge.gov.br. the heterogeneity of indicators. However, despite the difficulty of such an exercise, this paper presents an initial approach to this issue based oninformation made available from the statistical offices of the three selected countries.

An indicator that may provide qualitative data about the extension of informality in these countries is the situation of housing tenure collected from population and housing censuses. In this way, the first relevant detail is that the Mexican office does not provide such information, even when taking into account that the dispute over the tenure of ejido and/or communal and urban lands is one of the main factors for the development of urban informality in the country. This indicator also shows that informality rises to 14.1 percent $^{15}$ and 9.9 percent $^{16}$ in Argentina and Brazil, respectively. Likewise, this factor allows an approximation to the universe that could potentially be subject to land-title regulatory policies in any of the three selected countries as it reveals the tenure condition of housing and land of registered households, thus becoming one of the key indicators for the identification of urban landtitle informality. However, this indicator does

152010 Census. National Institute of Statistics and Census. www. indec.gov.ar.

162010 Census. Brazilian Institute of Geography and Statistics. www.ibge.gov.br. 
obstante, nada dice sobre las condiciones urbanísticas y ambientales de dichos hogares.

Por ello, para aproximarnos a las necesidades de regularización urbanística y ambiental se pueden tomar otros indicadores, de los cuales seleccionamos tres: acceso al agua corriente de red, acceso al sistema de desagüe y disponibilidad de inodoro con arrastre de agua en la vivienda. Los dos primeros indicadores permiten aproximarnos a la existencia de redes de servicios de infraestructura básicos en las viviendas, que es una de las necesidades fundamentales en términos de consolidación de los barrios de origen informal. El tercer indicador, en cambio, nos habla de la capacidad de inversión y mejora por parte de los hogares de la infraestructura y el equipamiento sanitario de su vivienda.

Los tres países muestran un nivel elevado y similar de acceso a la red de agua corriente. No obstante, es muy dispar el acceso al sistema de desagüe: México, 88,8\% ${ }^{17}$; Argentina, 77,8\%; y llama la atención lo bajo del porcentaje de este indicador en Brasil (55\%). De manera similar se distribuye la disponibilidad de inodoro con arrastre de agua, ubicándose México en un nivel muy elevado de disponibilidad (93,9\%), seguido de Argentina $(87,3 \%)$, y muy por debajo, con niveles muy bajo de disponibilidad, Brasil (55,4\%).

17 Los datos de México corresponden al Censo 2010. Instituto Nacional de Estadística y Geografía. www.inegi.org.mx. not provide any type of information regarding the urban and environmental conditions of dwellings.

Therefore, urban and environmental regulatory needs can be approached through the use of three indicatorspreviously selected for this purpose: access to drinking water, access to sewage systems and availability of flush toilets. The first two indicators provide approaches to the existence of basic infrastructure networks in dwellings, which is one of the essential needs for the consolidation of informal neighborhoods. The third indicator deals with the investment ability and improvement of households in terms of infrastructure and sanitary equipment.

The three selected countries show similar high levels of access to drinking water. However, there are considerable differences in the access to sewage systems: Mexico, 88.8 percent $^{17}$, Argentina, 77.8 percent and Brazil, with a surprisingly low value (55 percent). The availability of flush toilets is also led by Mexico, with very high availability levels (93.9 percent), followed by Argentina (87.3 percent) and Brazil, with very low availability levels (55.4 percent).

172010 Census, National Institute of Statistics and Geography. www.inegi.org.mx. 
Otro indicador relevante para aproximarnos a la informalidad urbanística y ambiental está referido a la calidad de los materiales constructivos de las viviendas, que dan cuenta del nivel ingreso, capacidad de inversión y nivel de consolidación de los barrios populares de origen informal. Con respecto este indicador es difícil trazar un paralelo, porque México no tiene o no publica un indicador sintético y presenta separados los datos con respecto a los materiales predominantes en pisos, las paredes y el techo; mientras que Brasil no publica o no releva ningún dato sobre calidad de los materiales constructivos. Argentina, en cambio, sí publica un índice sintético denominado CALMAT (calidad de los materiales), cuyo nivel observado es bastante elevado: un 38,4\% de viviendas construidas con materiales precarios.

Este diagnóstico, si bien muy preliminar, nos permite vislumbrar el porcentaje elevado de población y de viviendas que están involucradas en la problemática del hábitat informal y que pueden ser destinatarios de políticas públicas de regularización dominial y urbanística.

En las siguientes secciones vamos a analizar la normativa urbana existente en cada país en relación con la regularización de la informalidad urbana, y vamos a detallar los principales organismos y programas, de nivel nacional, involucrados en la materia.
The other indicator used to addressurban and environmental informality is related to the quality of construction materials, which reveal the income level, investment ability and consolidation level of informal neighborhoods. As for this factor, it is difficult to make comparisons between countries since Mexico does not have or does not provide a synthetic indicator and offers separated data regarding the main materials used in floors, walls and ceiling and Brazil does not provide or does not reveal any type of information concerning the quality of construction materials. However, Argentina does provide a synthetic indicator called CALMAT (quality of materials); it is worth noting that the observed level of this indicator is rather high, with 38.4 percent of dwellings constructed of poor materials.

Though preliminary, such a diagnosis allows a glimpse of the high percentage of the population and dwellings involved in the issue of informal habitat that may be recipient of land-title and urban regulatory policies.

The following sections of this research analyze the current urban regulations of each country in relation to the regularization of urban informality and offer details about the main local entities and programs involved. 


\section{Las políticas de regularización}

Se pueden distinguir tres tipos de políticas de regularización: i) aquellas que tienen por objetivo sanear la situación dominial; ii) aquellas que tienen por objetivo sanear la situación urbano-ambiental y iii) las integrales que articulan i) y ii) ${ }^{18}$ Las experiencias de políticas de regularización integral han sido escasas. Generalmente, las políticas de regularización se implementaron de manera desarticulada, siendo mucho más extendidas las políticas de tipo i. Ello se debió a que este tipo de intervenciones es menos costoso, tiene mayor visibilidad en términos políticos y ha recibido una fuerte promoción de parte de algunos organismos internacionales por sus supuestos efectos multiplicadores.

Las políticas de regularización surgieron en la década de 1960, especialmente en aquellos países como Perú y México donde las elevadas exigencias normativas y la falta de mecanismos de acceso al suelo propiciaron la extensión de situaciones de informalidad masivas, alcanzando en algunas ciudades a la mitad o más de la población.

Si bien son preexistentes, estas operatorias fueron impulsadas masivamente por los organismos internacionales de crédito durante la década de

18

18 Clichevsky, 2003.

\section{Regulatory policies}

There are three types of regulatory policies: i) those aimed at stabilizing the land-title situation; ii) those aimed at stabilizing the urbanenvironmental situation and iii) those integral policies aimed at linking type i) and ii) policies ${ }^{18}$, the latter being the least used. In general terms, these regulatory initiatives have been implemented independently, the most demanded being type i) policies. The popularity of this type of initiative is based on its low cost, greater scope in political terms and support provided by international organizations, which recognize its alleged multiplier effects.

These regulatory policies emerged during the 1960s, particularly in countries like Peru and Mexico, where tough regulatory requirements and the lack of mechanisms for land access favored the spread of informality at a large scale, reaching more than half of the population of some cities.

Although pre-existent, these initiatives were largely promoted by international credit agencies during the 1990s. Influenced by the thesis of Hernando de Soto ${ }^{19}$, such entities considered that land-title regularization would have a positive impact on

\footnotetext{
18 Clichevsky, 2003.

19 De Soto, Ghersi y Ghibellini, 1986.
} 
1990. Influidos por la tesis de Hernando de Soto ${ }^{19}$, entendieron que la regularización dominial tendría por sí misma efectos beneficiosos en las condiciones de vida de la población al promover su inserción social y facilitar la integración en otras esferas tales como la laboral, educativa, etc. Pese a esto, en algunas experiencias estas políticas fueron resignificadas por las organizaciones de los barrios que impulsaron iniciativas de autogestión del hábitat. No obstante, los procesos no necesariamente han concluido de manera exitosa y tampoco han provocado los efectos sociales y económicos previstos. En numerosas situaciones, aun cuando se lograron concluir los procesos de regularización se desarrollaron nuevos procesos de informalización asociados a problemas de sucesión, de subdivisión, de venta y/o alquiler en el mercado inmobiliario informal, lo cual tiende a desmitificar algunos de los potenciales efectos beneficiosos de las políticas de regularización.

En el contexto de dinamización de estas políticas durante la década de $1990^{20}$, la reforma del Estado y la reestructuración económica impactaron fuertemente en el funcionamiento del mercado de suelo urbano y generaron cambios profundos en las políticas de regularización implementadas. Desde entonces, el paradigma de políticas habitacionales se traslada de las políticas de vivienda tradicional,

9 De Soto, Ghersi y Ghibellini, 1986.

20 Clichevsky, 2006b. the life conditions of the population through the promotion of inclusivity and integration into labor and educational spheres, among others.However, in some cases, these policies were redefined by the organizations of neighborhoods that promoted housing self-management initiatives. Despite this, some of these processes have not met with success and have also failed to cause the expected social and economic changes. Occasionally, new informality processes emerged as the result of succession, subdivision and informal sale and/or rent issues right after a regulatory process was over; such a situation demystifies some of the potential positive effects of regulatory policies.

Within the context of the improvement of these initiatives over the $1990 \mathrm{~s}^{20}$, State reforms and economic restructuration had a great impact on the operation of the urban land market, which led to radical changes in the implemented regulatory policies. Since then, the housing policy paradigm moved to traditional housing policies, then to the provision of serviced plots and finally, thanks to the support of the Inter-American Bank and the World Bank, to the legalization and improvement of neighborhoods. It is worth pointing out that land-title regulatory policies operate more freely in public lands rather than in private lands; this is 
a los lotes con servicio y posteriormente a la legalización y mejoramiento de barrios, auspiciados por los organismos internacionales como el Banco Interamericano de Desarrollo y el Banco Mundial. Las políticas de regularización dominial han avanzado mucho más sobre tierras públicas, que sobre tierras privadas, donde el Estado debe primero expropiar o ser mediador -no desinteresado- en una negociación. Asimismo, debe destacarse como un antecedente histórico relevante la II Conferencia Hábitat de la Organización de Naciones Unidades de 1996, donde se definió a la tenencia segura como uno de los objetivos fundamentales de los gobiernos, dando un nuevo espaldarazo a este tipo de operatorias.

En este marco, los tres países tienen marcos normativos bastante disímiles en lo que hace a las cuestiones habitacionales, pese a que comparten el régimen federal de organización del Estado Nacional y abrevan en tradiciones y fuentes comunes del derecho.

La Constitución Argentina establece en su artículo 17 la inviolabilidad de la propiedad privada. Por otra parte, el artículo 14 bis establece el derecho a una vivienda digna y el artículo 41 establece el derecho a un ambiente sano. Esta conjunción de derechos, que muchas veces colisionan en realidad, debe ser resuelta políticamente por las autoridades competentes (tanto el legislativo como el ejecutivo) o en última instancia por el poder judicial, ambos because, within a private context, the State has to expropriate and then become a (non-disinterested) mediator in the case of a negotiation.

Likewise, the 1996 Habitat II Conference should be regarded as historical since this convention defined secure tenure as one of the key goals of governments, thus providing a new boost to this type of operation.

In this sense, the three selected countries, though sharing the same federal system as well as traditions and sources of law, have different regulatory frameworks regarding housing issues.

Article 17 of the Argentinean Constitution declares the inviolability of private property. On the other hand, article 14 bis declares the right to decent housing and article 41 declares the right to a healthy environment. This conjunction of rights, which are in constant conflict with reality, should be resolved politically by the pertinent authorities (legislative and executive) or, ultimately, by the justice departmentwithin a context marked by high social tensions. In other national constitutions, even in some provincial constitutions of Argentina, the inclusion of the legal principle of the social function of property is a strong argument in favor of the primacy of the social interest over the individual proprietary interest that may contribute to resolve this conflict 
en un contexto marcado por una gran conflictividad social. En otras constituciones nacionales, incluso en algunas constituciones provinciales de Argentina, la inclusión del principio jurídico de la función social de la propiedad es un argumento potente a favor de la primacía del interés social por sobre el interés individual patrimonial que puede ayudar a resolver dicha confrontación de derechos. El Código Civil es la ley fundamental que regula todo lo atinente a la propiedad de la tierra y de la vivienda, pero lo hace enmarcándose en los principios constitucionales de la inviolabilidad de la propiedad, tomando un claro sesgo patrimonialista que repercute en general en las sentencias y en la jurisprudencia. Esto genera grandes obstáculos en materia de regularización dominial, porque en general tiende a primar el derecho de propiedad irrestricto, por sobre otras consideraciones, como la función social de la propiedad.

En este marco es notoria la ausencia de una política de regularización unívoca a nivel nacional. Los pocos intentos de articular una política integral y universal fracasaron, recayéndose una y otra vez en la sanción de normativa específica para cada caso, segmentando las soluciones y vulnerando el principio de igualdad ante la ley de los habitantes. Esta situación expresa, en parte, un cierto consenso del sistema político acerca de no cuestionar las relaciones de propiedad y el acceso a la tierra y a la vivienda, poniendo a la propiedad privada por encima de los derechos sociales, económicos y culturales de las familias de menores of rights. The Civil Code is the basic law that regulates everything related to land and housing property; however, such a regulation is framed within the constitutional principles of property inviolability, thus adopting a property bias that has effects on verdicts and jurisprudence. This situation leads to obstacles in terms of land-title regularization since the unlimited right to property tends to win out over other considerations, emerging as the social function of property.

In this sense, there is a conspicuous lack of a univocal regulatory policy at national level. The few attempts to link integral and universal policies have met with nothing but failure as specific regulatory verdicts are used for each case, thus segmenting the provision of solutions and violating the principle of equity under the law. Such a situation, instead of recognizing the existence of a struggle between two legit rights that should be addressed by the proper channels partly expresses a certain consensus within the political system on not questioning ownership relations and the access to land and housing; this puts private property over the social, economic and cultural rights of low-income families.

Within the framework of the State reform and the implementation of neoliberal measures, different 
ingresos, en vez de reconocer que existe una pugna entre dos derechos legítimos que debe ser procesada por las instancias adecuadas.

En el marco de la reforma del Estado y de la aplicación de las medidas de corte neoliberal se sancionaron algunas normativas que habilitaron mecanismos de transferencia y regularización de tierras para el hábitat de sectores populares:

- En 1989, la Ley de Emergencia Económica No 23.697 habilitó la posibilidad de que el Estado Nacional transfiera a privados la propiedad de tierras fiscales que previamente fueran declaradas innecesarias para la gestión.

- De manera similar, el Decreto 1.001 de 1990, habilitó la transferencia de las tierras fiscales sobre las que se asentaban las villas de emergencia de la Ciudad de Buenos Aires. El Decreto 2.411 de 1990 extiende este mismo criterio para todas las villas del Gran Buenos Aires.

- Asimismo, la Ley 23.967 de 1991 transfiere tierras en propiedad del Estado Nacional que se hallen ocupadas por viviendas permanentes y que sean innecesarias para el cumplimiento de su gestión, a las Provincias y Municipios para su posterior venta o incorporación a planes sociales de vivienda social.

- La Ley 24.374 de 1994, conocida como "Ley Pierri" habilitó la transferencia de tierras privadas a sus ocupantes reales. El objetivo era regulations aimed at enabling the transfer and regularization of land in popular areas were adopted:

- In 1989, the Economic Emergency Act $n^{\circ} 23697$ enabled the State to transfer unnecessary public lands to private parties.

- Similarly, Decree $n^{\circ} 1001$ of 1991 enabled the transfer of public lands over which the shanty towns of the City of Buenos Aires were located. Decree 2,411 of 1990 extends such criteria to all of the villages of Greater Buenos Aires.

- Likewise, Act $n^{\circ} 23967$ of 1991 transferred unnecessary State-owned lands occupied by permanent dwellings to their respective Provinces and Municipalities for their subsequent sale or incorporation into social housing plans.

- Act $n^{\circ} 24374$ of 1994, known as the "Pierri Act", enabled the transfer of private lands to their actual owners. The objective of this proposal was to shorten the twenty-year possession, or acquisitive prescription, enshrined in the Civil Code and enable administrative resolutions rather than long and expensive resolutions issued in courts. 
acortar los plazos del instituto jurídico de la posesión veinteañal o usucapión del Código Civil y posibilitar una resolución por vía administrativa que evitar la resolución en sede judicial mucho más larga y costosa.

- Otra de las normativas relevantes en términos de regularización es el instituto de la expropiación, que fue adaptándose también para su implementación en urbanizaciones informales. La expropiación garantiza la ocupación y elimina el riesgo de desalojo, sin contemplar necesariamente acciones tendientes a la regularización de la urbanización ni a la transferencia del dominio.

La Constitución de Brasil de 1988 incorporó la función social de la propiedad en sus artículos 5, 170 y 182. Este último habla específicamente la propiedad urbana y establece que se puede limitar la propiedad en aras de las exigencias de ordenación de la ciudad expresadas en los planes directores. El artículo 183 establece que cualquier persona, que no posea otra propiedad inmueble, que ocupe pacíficamente y sin oposición por el plazo de cinco años una parcela de hasta 250 metros cuadrados, que no sea de dominio público, tiene derecho a pedir la transferencia de su propiedad por usucapión. Este instrumento jurídico, aunque fue poco aplicado, tiene un gran potencial en aras de facilitar la regularización dominial.
- Expropriation is another important regulatory measure that had to adapt itself for the purpose of being implemented in informal towns. Expropriation ensures occupation and eliminates eviction risks; this measure does not necessarily involve actions related to urban regulation or transfer of property.

The Brazilian Constitution of 1988 incorporated the social function of property in articles 5, 170 and 182, the latter detailing urban property and establishing restrictions on property according to the planning requirements of the city. Article 183 establishes that any person who does not have another property and peacefully and without opposition occupies a non-public plot measuring up to 250 square meters for a period of five years has the right to ask the transfer of his property by way of acquisitive prescription. Though underused, this legal instrument has a great potential when it comes to facilitate landtitle regulation.

The constitutional reform of 1988 granted more participation and decision-making power to the municipalities in the formulation of urban policies and therefore most of the proposed initiatives occur at that level; such a fact complicates 
La reforma constitucional de 1988 otorgó mayor participación y decisiones a los municipios en la formulación de la política urbana, por lo que gran parte de las políticas formuladas se dan en ese nivel, lo que dificulta la comparación entre países. Los municipios son los encargados de formular los Planes Directores, que son uno de los principales instrumentos de gestión urbana. La Unión Federativa se encarga de trazar mediante leyes federales las principales directrices de la política urbana.

El caso de Brasil es mucho más rico en normativa cuyo desarrollo obedece a la presencia de un movimiento social potente: el Movimiento Nacional por la Reforma Urbana. Originado en enero de 1985 e institucionalizado como Foro Nacional de la Reforma Urbana en 1987, fue uno de los impulsores de la reforma constitucional de 1988.

Uno de las principales leyes que siguieron a la sanción de la nueva constitución fue la Ley Federal 10.257, denominada Estatuto de la Ciudad, que reglamenta los artículos 182 y 183 de la Constitución. Su sanción fue muy demorada y compleja, recién se produjo en 2001, trece años después de la reforma de la Carta Magna. Por la organización Federal del Estado de Brasil, el estatuto sólo establece una serie de principios e instrumentos a este fin, que sirven de marco general para las políticas urbanas de los Municipios.

También incorporan un instrumento preexistente, las Zonas Especiales de Interés Social, creadas por comparisons among the three analyzed countries. Municipalities have the task of formulating Master Plans, the latter being some of the most important urban management instruments. The Federal Union is in charge of elaborating, through federal laws, the main regulations regarding urban policies.

The Brazilian case, apart from offering regulatory experiences, owes its development to a strong social movement: the National Movement for Urban Reform. Such a movement was born in January, 1985 and institutionalized as the National Forum on Urban Reform in 1987 and was some of the first promoters of the 1988 constitutional reform.

One of the main laws adopted in the new constitution was the Federal Act $n^{\circ} 10257$ entitled Statute of the City; this ordinance regulates articles 182 and 183. This long-delayed and complex law was enacted in 2001, thirteen years after the reform to the Magna Carta. Given the organization of the Brazilian State, this act sets only a series of principles and instruments which are used as the general framework of municipal urban policies.

Likewise, these policies also incorporate an already existing instrument, the Special Zones of Social Interest created by the Municipality of Recife 
la Municipalidad de Recife en 1987. Esta figura facilita la regularización de asentamientos informales y permite a su vez diseñar áreas para la ocupación popular, porque habilita el establecimiento de índices urbanísticos diferenciados. No obstante, este instrumento no modifica concretamente la situación de la tenencia, ni la percepción de la seguridad de la tenencia, sino que apenas sirve para eliminar el riesgo de los desalojos ${ }^{21}$. Incluso puede llegar a causar desplazamiento de la población más vulnerable dentro de los asentamientos informales.

En los últimos años la política de vivienda de la gestión del Partido dos Trabalhadores fue produciendo un giro privatista, con mayor participación del capital privado y las empresas constructoras y desarrolladores urbanos, después de un origen en donde se hacía más hincapié en las políticas de autogestión y producción social del hábitat ${ }^{22}$. En este sentido, se acercó más a diseños como los de la política de subsidios habitacionales de Chile. El punto culminante de este giro es la sanción en 2009 de la Ley Federal 11.977, que regula el Programa "Minha Casa, Minha Vida". Esta ley se ocupa fundamentalmente del financiamiento a la vivienda nueva, pero está integrada por un capítulo específico sobre regularización fundiaria de asentamientos informales, por eso la incluimos en este trabajo. Incluye tanto la regularización jurídica -títulos-,

21 Souza y Zetter, 2004.

22 Arantes, 2011.
In 1987. Such a form facilitates the regularization of informal settlements and enables the design of areas for popular occupation through the setting of differentiated urban indicators. However, this instrument does not modify the situation of tenure or the perception of secure tenure, but only eliminates the risk of eviction ${ }^{21}$. It can even cause the displacement of vulnerable people within informal settlements.

Over the last years, the housing policy of the Labor Party has adopted a private approach, with an increasing involvement of private capital, building firms and urban developers; this situation is different from that of the early days of the party, in which self-management and social production of habitat were the focus of discussions ${ }^{22}$. In this sense, the initiatives promoted by the party were similar to that of Chilean policies on housing subsidies. The culmination point of this process took place in 2009 with the enactment of Federal Act $n^{\circ} 11977$, which was intended to regulate the My House, My Life Program. Despite dealing essentially with the financing of new housing, this law contains a specific chapter about the real property regulation in informal settlements, thus becoming a relevant piece of information or the purpose of this research. This act includes legal (deeds), urban

21 Souza y Zetter, 2004.

22 Arantes, 2011. 
como urbanística y ambiental. Establece criterios para considerar cuándo un asentamiento informal está regularizado fundiariamente: densidad demográfica superior a 50 habitantes por hectárea, tendido de calles y al menos dos de los siguientes servicios de infraestructura: desagüe pluvial o cloacal, agua potable, energía eléctrica, limpieza urbana. La regularización, además, puede ser individual o colectiva a nombre de cooperativas, asociaciones, fundaciones, organizaciones sociales, etc.

La Constitución de México incorpora desde 1917 limitaciones a la propiedad privada en pos de garantizar su función y beneficio sociales. De hecho, el artículo 27 establece que las tierras son de propiedad originaria de la Nación, que tiene el derecho de transferirlas a los privados, constituyendo así la propiedad privada. No obstante, guarda para sí el derecho de imponer a la propiedad privada las modalidades que dicte el interés público, así como de regular en beneficio social el aprovechamiento de los elementos naturales susceptibles de apropiación (como la tierra), de donde se deriva el interés público y beneficio social que debe regir la planificación urbana. Además, establece en su artículo 4 el derecho a un medio ambiente adecuado, una vivienda digna y decorosa. De esta reforma constitucional se heredó el complejo régimen jurídico de tierras de México que reconoce tierras rurales de propiedad y uso colectivo, las tierras ejidales y las tierras comunales que si bien difieren en su origen tienen un tratamiento muy similar. and environmental regularization. Likewise, it also sets the criteria used to determine if an informal settlement is regularized in terms of property: demographic density over 50 inhabitants per hectare and street paving; and in terms of at least two of the following infrastructure services: rainwater drainage, sewer system, drinking water, electricity or street cleaning. Additionally, regularization could be either individual or collective, the latter including cooperatives, associations, foundations, social organizations, etc.

Since 1917, the Constitution of Mexico includes restrictions on private property to ensure their proper operation and social benefits. In fact, article 27 sets out that lands are originally property of the Nation, which has the right to transfer them to private parties, thus constituting private property. However, the State holds the right to impose on private property the modalities emanated from the public interest and regulate, for social wellbeing, the use of the natural elements that may be appropriated (such as land) and from which public interest and social wellbeing that should govern urban planning derive. Likewise, article 4 declares the right to a proper environment and to decent and adequate housing. This constitutional reform 
En México, por su parte, la política de regularización se inicia en la década de 1970 y es una de las más antiguas de la región, junto con Perú. De todas maneras, lo más dinámico del proceso se da también durante la década de 1990. En la actualidad gran parte de la política de regularización se desarrolla a nivel federal y está enfocado mucho más a la titularización masiva que a la regularización urbanísticas de los asentamientos. La sanción de la Ley General de Asentamiento Humanos de 1976 implicó un punto de inflexión en la normativa urbana de México ${ }^{23}$. Si bien, la enmarca en un proceso más general de generación de normativa, también la vincula a los conflictos urbanos emergentes en la década de 1960, especialmente en el Distrito Federal. Estos conflictos se vinculaban al crecimiento urbano descontrolado, con un alto componente de informalidad. Asimismo, en 1988 se sanciona la Ley General de Equilibrio Ecológico y Protección Ambiental, que en su artículo 23 regula ambientalmente los asentamientos humanos.

Gran parte de las situaciones de informalidad urbana están vinculadas a las tierras ejidales o comunales. Se calcula que el $66 \%$ de las tierras que rodean a las ciudades son de este origen. Hasta antes de la reforma constitucional de 1992 los núcleos agrarios no podían disponer libremente de sus tierras, los derechos de propiedad sobre sus tierras eran definidos como inalienables, inembargables e

23 Ovilla Mandujano, 1984. inherited the complex Mexican legal system of land that recognizes the similarly treated ejido and communal lands as rural lands intended for collective ownership and use.

In the same vein, Mexico began the implementation of regulatory policies during the 1970, which, along with that of Peru, are among the oldest of the region.However, the most dynamic phase of this process took place during the 1990s. Today, most of regulatory policies are developed at federal level and focus more on the massive provision of title deeds than on the urban regularization of settlements. The General Act on Human Settlements of 1976 marked a turning point for the urban regulation of Mexico ${ }^{23}$. Such a law frames these regulations in a general process of policy generation and also relates them to the urban conflicts that emerge back in the 1960s, especially in the Federal District. These disputes were related to an uncontrolled urban growth that included high levels of informality. Likewise, article 23 of the General Act on Ecological Balance and Environmental Protection, enacted in 1988, ensured the environmental regulation of human settlements.

23 Ovilla Mandujano, 1984. 
imprescriptibles. Esto implicó la formación de un mercado que generó asentamientos en áreas altamente vulnerables. Los ocupantes muchas terminaron pagando dos veces, una al ejido, y otra al Gobierno Federal para que expropie al ejido.

En 1992, después de la última reforma constitucional, se sanciona la ley Agraria que establece la propiedad por parte de los ejidos. Regula el destino, uso, usufructo y las condiciones en que pueden ser cedidas o transferidas, especialmente cuando estas se hallan en zonas urbanas o en áreas de crecimiento de un centro de población. Esta ley fue vital para la regularización de las colonias asentadas en tierras ejidales y comunales, porque habilita la expropiación de las tierras, entre otras razonas para la regularización de la tenencia de la tierra urbana y rural y establece además mecanismos para que las tierras ejidales y comunales se puedan incorporar al desarrollo urbano.

\section{Los principales organismos y programas de regularización dominial y urbanística}

\section{ORGANISMOS Y PROGRAMAS DE ARGENTINA}

En Argentina se pueden mencionar tres organismos fundamentales de nivel nacional que implementan políticas de regularización.
Most of urban informality situations are linked to ejido or communal lands. It is estimated that 66 percent of lands surrounding cities are communal lands. Before the constitutional reform of 1992, all rural areas could not freely dispose of their lands and the property rights of ownership on their lands were regarded as inalienable, unattachable and non-lapsable. This resulted in the emergence of a market that created settlements in highly vulnerable areas. In many cases, the occupants of these lands ended up paying twice as much for their lands: one payment to the ejido and the other payment to the Federal Government to expropriate the ejido.

In 1992, after the last constitutional reform, the Rural Act was enacted, establishing the ownership of ejido lands. Such a law regulates the destination, use, usufruct and the conditions for the assignment or transfer of ejidos, especially when they are located in urban areas of growing population centers. This act is vital for the regularization of settlements established in ejidos as it enables the expropriation of lands and sets the mechanisms for the incorporation of ejidos into the urban development, among other reasons for the regularization of urban and rural land tenure. 
En primer lugar, la Subsecretaría de Desarrollo Urbano y Vivienda, que es la encargada de la implementación de los programas federales de vivienda. Sólo algunos de estos se ocupan de la regularización dominial y urbanísticas de asentamientos informales. El grueso del presupuesto se destina a la construcción de viviendas nuevas.

En segundo lugar, la Comisión Nacional de Tierras Fiscales. Emplea mayoritariamente el mecanismo de transferencia colectiva de tierras a organizaciones sociales conformadas por los ocupantes, obviando requisitos que demorarían el trámite (subdivisiones, arreglos normativos, proyectos urbanos). La población objetivo son familias de escasos recursos asentadas pacíficamente en tierras fiscales nacionales, con destino a vivienda única y permanente. Proyecta solución para 600 mil personas en villas o asentamientos irregulares. El precio simbólico es de U\$S $2 / \mathrm{m}^{2}$. Hasta 2004 se habían transferido tierras en 384 barrios de 105 municipios, involucrando a 381.350 beneficiarios.

En tercer lugar, la Comisión Nacional de Tierras para el Hábitat Social (Decreto No 158/06), que absorbió y reemplazó a la anterior. Este organismo tiene como finalidad apoyar, promover y facilitar los procesos de acceso a la propiedad de la tierra individual y/o colectiva que las comunidades llevan adelante, colaborando en la consolidación y mejoramiento de la calidad habitacional de grupos de pobladores urbanos y rurales en coordinación

\section{Main Land-Title and Urban Regulatory Agencies and Programs}

\section{AGENCIES AND PROGRAMS IN ARGENTINA}

There are three main agencies at national level in charge of implementing regulatory policies:

The first of these agencies is the Under-Secretariat for Urban Development and Housing, which is in charge of the implementation of federal programs on housing. Only a few of these programs address the land-title and urban regularization of informal settlements. Most of the resources allocated to this agency are intended for the construction of new dwellings.

The second agency is the National Commission on Public Lands. This body mostly deals with the collective transfer of land to social organizations constituted by the occupants themselves, thus bypassing requirements that may delay such an operation (subdivisions, legal arrangements, and urban projects). This program is intended to assist low-income families who live pacifically in public lands that may eventually have access to a unique and permanent housing. The symbolic price is US\$ 2 per square meter. As of 2004, 384 lands within neighborhoods of 105 municipalities have been transferred, involving 381,350 beneficiaries. 
con los diferentes niveles del Estado. Financia obras y/o servicios de infraestructura y equipamiento básico, asistencia habitacional a comunidades específicas y fortalecimiento institucional de cooperativas y organizaciones sociales.

Uno de los principales instrumentos de regularización dominial aplicados en Argentina, específicamente en la Provincia de Buenos Aires, fue la mencionada Ley 24.374, pero que se implementó a través de un convenio específico con el Colegio de Escribano de la Provincia de Buenos Aires a través de lo que se denominaron "Casas de Tierras" donde se implementaba la operatoria de manera descentralizada.

\section{ORGANISMOS Y PROGRAMAS DE BRASIL}

El principal organismo en la materia, de nivel federal, es el Ministerio de las Ciudades, siendo uno de los pocos países que tiene un organismo de esta jerarquía vinculado a cuestiones específicamente urbanas. Este ministerio tiene cuatro Secretarías Nacionales: Vivienda, Saneamiento, Programas Urbanos, y Transporte y Movilidad; siendo la primera la que canaliza la mayor parte de los programas de regularización. Entre los principales programas se destacan:

Los programas implementados a través de la Secretaría de Vivienda son:

- Programa "Minha Casa, Minha Vida" (Secretaría de Vivienda), regido por la Ley Federal 11.977,
The third agency is the National Commission on Lands for Social Habitat (Decree $n^{\circ}$ 158/06), which replaced the aforementioned agency. The goal of this commission is to assist, promote and facilitate the access processes to individual and/or collective lands led by communities and, in coordination with the different levels of State, consolidate and improve the housing quality of urban and rural dwellers. This agency also funds infrastructure works and/or services, provides basic amenities and housing assistance to specific communities and contributes to the institutional strength of cooperatives and organizations.

One of the main instruments for land-title regularization applied in Argentina, particularly in the Buenos Aires Province, was the previously mentioned Act n²4374; however, this law was applied through a specific agreement with the Notary Public Association of the Buenos Aires Province; this process gave them the name of casas de tierras, in which the implemented tenure procedures were carried out on a decentralized basis.

\section{AGENCIES AND PROGRAMS IN BRAZIL}

At federal level, the main agency on this matter is the Ministry of Cities. This is one of the few countries in the world to have a ministerial body in charge of urban issues. This Ministry has four National Secretariats: Housing, Health, Urban Programs and Transport and Mobility; the former 
integra un capítulo específico sobre la regularización dominial en asentamientos informales.

- Programa de Urbanización, Regularización e Integración de Asentamientos Precarios (Secretaría de Vivienda): brinda apoyo al mejoramiento de las condiciones habitacionales de asentamientos precarios.

- Proyectos Prioritarios de Intervención en Favelas (Secretaría de Vivienda): brinda apoyo al mejoramiento de condiciones habitacionales de asentamientos precarios.

- Programa Habitar Brasil (Secretaría de Vivienda), co-financiado por el BID (Préstamo 1125 OC/BR) y la Caja Económica Federal desde 1997, está orientado a la promoción de las condiciones habitacionales en asentamientos informales.

- Programa Pro Moradia (Secretaría de Vivienda). Promueve la urbanización y regularización de asentamientos precarios.

- Programa Nacional de Apoyo a la regularización dominial sostenible - "Papel Passado" (Secretaría de Programas Urbanos): Tiene como objeto proveer a los pobladores de asentamientos precarios con ingresos inferiores a U\$S 300 la legalización de la tierra. Hasta junio de 2005 había 509 mil familias con procesos de regularización iniciados en 461 asentamientos. channeling most of regulatory programs. Some of the main programs implemented by the Housing Secretariat are listed as follows:

- My House, My Life Program, regulated by Federal Act $n^{\circ} 11977$. This program contains a specific chapter on land-title regulation in informal settlements.

- Program on Urban Development, Regularization and Integration of Precarious Settlements. This program promotes the improvement of the housing conditions of precarious settlements.

- Intervention Priority Projects in Favelas. These projects promote the improvement of the housing conditions of precarious settlements.

- Brazil Inhabit Program. This program is cofunded by the IADB (Loan 1125 OC/BR) and the Caixa Economica Federal since 1997 and is focused on the promotion of the housing conditions of informal settlements.

- Pro Housing Allocation Program. This program promotes the urban development and regularization of precarious settlements. 
Asimismo, existen algunas experiencias implementadas por niveles de gobierno estaduales y municipales, entre las que se destaca el Programa de Urbanización de Asentamientos Populares de Rio de Janeiro, conocido como "Favela Barrio". Pese a no ser de nivel nacional, es uno de los programas más importantes. Cuenta con financiamiento del BID y sirvió de modelo para la formulación de otros programas de la región.

\section{ORGANISMOS Y PROGRAMAS DE MÉXICO}

El principal organismo vinculado a las políticas de regularización en el organigrama del Gobierno Federal de los Estados Unidos de México es la Secretaría de Desarrollo Social (SEDESOL). Esta Secretaría incluye una serie de Subsecretarías que implementan programas de infraestructura, equipamiento y hábitat social en barrios populares. Es decir, se ocupan de la regularización urbanística y ambiental de dichos barrios.

Como se explicó más arriba, una de las principales fuentes de la informalidad urbana en México es la urbanización informal de las tierras ejidales o comunales. En 1973 el Gobierno Federal creó el Comité para la Regularización de la Tenencia de la Tierra (CORETT) que concentra la regularización dominial de las urbanizaciones informales, vía expropiación, transferencia y titularización masiva de las tierras. Lleva regularizado más de más de 2,5 millones de lotes, mientras que están
- National Support Program for Sustainable Land-Title Regularization - "Legal Papers". This program is aimed at dwellers of precarious settlements who earn less than US\$300 and provides them with legal security of tenure. As of June, 2005, 509 families from 461 settlements were involved in regulatory processes.

Likewise, there are some experiences implemented at state and municipal levels, chief among which is the Program for the Urban Development of Popular Settlements in Rio de Janeiro, also known as Favela Bairro. Despite not being national in scope, this initiative is listed as one of the most important programs; it is also funded by the IADB and serves as a model for the elaboration of other programs throughout the region.

\section{AGENCIES AND PROGRAMS IN MEXICO}

The main agency related to regulatory policies within the Federal Government of the United States of Mexico is the Secretariat for Social Development (SEDESOL). This entity includes a series of under-secretariats in charge of implementing infrastructure and social housing programs, as well as the provision of amenities, in popular neighborhoods. In other words, they deal with the urban and environmental regulation of these areas. 
en proceso de titulación más de un millón de familias $^{24}$. La mayor parte de las regularizaciones se encuentran sobre tierra ejidal y comunal, pero también interviene en los casos de tierra privada. También promueve la expropiación concertada de tierras ejidales ociosas para facilitar su incorporación al desarrollo urbano.

Asimismo, en 1993 el Programa de Certificación de Derechos Ejidales y Titulación de Solares Urbanos (PROCEDE) que tiene por objeto dar seguridad jurídica en la tenencia de la tierra a los integrantes de los ejidos. Tiene una cobertura 29.951 ejidos y comunidades agrarias que agrupan a 3,5 millones de ejidatarios y comuneros, así como 4,6 millones de parcelas y 4,3 millones de terrenos urbanos.

\section{Conclusión}

En primer lugar, es necesario reflexionar sobre el rol de los gobiernos nacionales en la formulación e implementación de política urbana y su relación con los otros niveles de gobierno. En este sentido, como se dijo, pese a ser tres países organizados políticamente como federaciones de estados, los roles que cumplen los gobiernos federales, estaduales y municipales difiere mucho. En Brasil, la reforma constitucional de 1988 puso un énfasis importante en el rol de los gobiernos locales, dotándolos de

24 Azuela, 2002.
As explained before, the informal urban development of ejido or communal lands is one of the sources of urban informality in Mexico. In 1973, the Federal Government created the Committee on Land Tenure Regularization (CORETT), an entity that focuses on the landtitle regularization of informal settlements by way of expropriation, transfer and massive titling of lands. As of today, this body has regulated more than 2.5 million plots and accounts for more than one million titling processes currently under way ${ }^{24}$. Most of regularizations involve ejido and communal lands but there are also some cases in which private lands come onto the scene. Likewise, this entity promotes the expropriation of unnecessary ejido lands to facilitate their incorporation into the urban development.

Similarly, the Certification Program of Ejido Rights and Titling of Urban Plots (PROCEDE), implemented in 1993, provides the dwellers of ejido lands with legal security of tenure. This program covers 29,951 ejido lands and rural communities that bring together more than 3.5 million rights holders of communal lands and local community members, 4.6 million agricultural fields and 4.3 million urban lands. 
una gran autonomía. Los municipios tienen una gran capacidad para generar recursos propios: están habilitados para la creación de impuestos, tasas, derechos u otros tributos. Pese a esto, el Estado Federal también jugó un rol fundamental en la tutela y regulación de la política urbana al sancionar el Estatuto de la Ciudad en 2001 y crear el Ministerio de las Ciudades.

En el otro extremo se ubica Argentina. Si bien impulsó un proceso de descentralización durante la década de 1990, la política urbana fue escasamente descentralizada. Los municipios tienen en términos formales la facultad de ordenamiento territorial, pero tienen escasa autonomía de recursos de los gobiernos provinciales y nacionales. El Gobierno Nacional, en este marco, mantiene un papel preponderante en el financiamiento, generando cierto desfasaje entre dotación de recursos y potestades legales que implica un elevado nivel de mediación política. La dependencia de la coparticipación federal de ingresos -que se rige por una ley que data de 1988-y, en los últimos años, de las transferencias por parte del gobierno central de los recursos superavitarios extrapresupuestarios son muy profundas. De ahí que los alineamientos políticos entre los diferentes niveles de gobierno sean determinantes para explicar la capacidad de formulación e implementación de políticas públicas por parte de los municipios.

\section{Conclusion}

Firstly, there is a need to reflect on the role of national governments in the elaboration and implementation of urban policies and their relation with other governmental levels. In this sense, despite being three countries organized as federal States, the functions carried out by their respective federal, state and municipal governments differ to a great extent. In Brazil, the reform of 1988 focused on the role of local governments, providing them with a great of autonomy. In this sense, municipalities have a strong capacity to generate their own resources: they are authorized to create taxes, fees, rights or other type of charges. However, the Federal State also played an important role in the supervision and regulation of urban policies with the enactment of the Statute of the City in 2001 and the creation of the Ministry of Cities.

On the other hand, despite encouraging a decentralization process during the 1990s, the urban policies promoted by Argentina failed to achieve such a goal. In formal terms, Argentinian municipalities have the ability to conduct territorial planning; however, provincial and national governments provide them with limited financial autonomy. Within this framework, the National Government has a dominant funding 
El caso de México, en alguna medida se encuentra en un punto intermedio, concentrando la Federación muchas de las funciones atinentes a la dinámica urbana (controla las principales políticas vinculadas a la regularización urbanística y ambiental, como la SEDESOL y CORETT). No obstante, los Estados han ganado en los últimos años una creciente autonomía.

En segundo lugar, se puede señalar la relación entre las políticas públicas de regularización y el régimen de propiedad de la tierra. Así, en el caso mexicano se destaca fundamentalmente el conflicto entre las tierras urbanas y las tierras rurales, específicamente las de origen ejidal o comunal. Poco se ha avanzado en la regularización de colonias o urbanizaciones informales en tierras privadas, lo que implica un sesgo por parte de las políticas de regularización en este país. En la Argentina se ha avanzado en la regularización de tierras de origen privado a partir de la implementación de la llamada Ley Pierri, que facilitó de manera limitada la transferencia de tierras a manos de sus ocupantes. Por fuera de esto, se pueden encontrar casos puntuales y resonantes de expropiación de tierras privadas, pero son casos minoritarios. En general, la regularización avanzó mucho más rápidamente en tierras de origen fiscal, porque fueron un efecto colateral de la reforma del Estado emprendida por los gobiernos neoliberales. En el caso de Brasil, nuevamente, la reforma constitucional, el estatuto de las ciudades, el ministerio de ciudades, son todas medidas que se enmarcan role, generating a certain gap between resource allocation and legal powers that requires high levels of political mediation. Likewise, there is a high dependency on the federal tax revenuesharing -governed by a law dating back to 1988- and, more recently, on the transfer of offbudget surplus made by the central state. This is why political guidelines among the different governmental levels are essential to explain the municipal capacity to elaborate and implement public policies.

In the case of Mexico, whichsits between the two aforementioned examples, many of the functions related to urban dynamics are dominated by the Federation (controlling the main policies linked to urban and environmental regulation such as the SEDESOL and the CORETT). However, over the last years, States have gained a great deal of autonomy.

In the second place, it is worth pointing out the relationship between the regulatory public policies and the property regime of land. In this way, the most remarkable fact of the Mexican case is the conflict between urban and rural lands, especially the ejido or communal lands. There has been little progress as far as the regularization of colonies or informal settlements in private lands is concerned, which implies a 
en el desarrollo de un dinámico Movimiento por la Reforma Urbana, que tenía como uno de sus objetivos plantear la necesidad de asegurar una función social de la propiedad y el derecho a la ciudad para todos los habitantes de las ciudades. Por ello, se dio un contexto mucho más propicio, aunque no exento de conflictos y contradicciones, para plantear limitaciones al derecho de propiedad en su concepción liberal más absoluta y se generaron herramientas que apuntaron a imponer o condicionar su ejercicio a los intereses más generales de la sociedad, entre los cuales se encontraba el desarrollo urbano equitativo y democrático.

\section{Bibliografía}

ARANTES, Pedro. Reforma urbana e autogestão no produto da cidade. Historia de um ciclo de lutas e desafios para a renovação da sua teoria e prática. En: Seminario producción social del hábitat y políticas habitacionales en las principales ciudades del cono sur $\left(1^{\circ}, 1\right.$ y 2 de diciembre de 2011, Buenos Aires, Argentina). Instituto de Investigaciones Gino Germani, Facultad de Ciencias Sociales, Universidad de Buenos Aires.

AZUELA, Antonio. El acceso de los pobres al suelo urbano de los ejidos. A diez años de la reforma. [En prevailing bias in local regulatory policies. The implementation of the Pierri Act facilitated the limited transfer of lands to their dwellers, which demonstrates the progress made on the regularization of private lands. Furthermore, despite being unusual, it is possible to find specific and relevant cases of expropriation of private lands. In general, regularization showed more progress on State-owned lands as they were a collateral effect of the State reform carried out by neoliberal governments. Again, in the case of Brazil, the constitutional reform, the Statute of the City and the Ministry of Cities are measures framed within the development of the dynamic Movement for Urban Reform, which had as some of its goals the need to achieve the social function of property and the right to the city for all. Despite some conflicts and contradictions, this situation generated an environment conducive to address the constraints to the right to property in its absolute liberal conception, thus generating mechanisms intended to impose or condition the way it operates in favor of the general interests of society, which included equitable and democratic urban development. 
línea]. En: Segundo seminario internacional reformas al suelo urbano. Aciertos, desaciertos y desafíos. México, Universidad Nacional Autónoma de México, Lincoln Institute of Land Policy. 2002. Disponible en: http://www.paot.org.mx/centro/ temas/suelo/unam/seminarios/segundo/2do_seminario.pdf

CLICHEVKSY, Nora. El mercado de tierras en el área de expansión de Buenos Aires. Su funcionamiento e incidencia sobre los sectores populares (19431973). Buenos Aires, Centro de Estudios Urbanos y Regionales-CEUR, Instituto Torcuato Di Tella. 1975.

CLICHEVSKY, Nora. Pobreza y acceso al suelo urbano. Algunos interrogantes sobre las políticas de regularización en América Latina. [En línea]. Santiago de Chile, CEPAL. 2003. Serie Medio Ambiente y Desarrollo $\mathrm{N}^{\circ}$ 75. Disponible en: http://www. eclac.org/cgi-bin/getProd.asp?xml=/publicaciones/xml/0/14390/P14390.xml\&xsl=/dmaah/tpl/ p9f.xsl\&base=/dmaah/tpl/top-bottom.xsl

CLICHEVKSY, Nora. Previniendo la informalidad urbana en América Latina y el Caribe. [En línea]. Santiago de Chile, CEPAL. 2006a. 71 p. ISBN 92-1322858-9. Serie Medio Ambiente y Desarrollo No 124. Disponible en: http://www.eclac.org/cgi-bin/ getProd.asp?xml=/publicaciones/xml/3/26133/ P26133.xml\&xsl=/dmaah/tpl/p9f.xsl\&base=/ dmaah/tpl/top-bottom.xsl

CLICHEVKSY, Nora. Regularizando la informalidad del suelo en América Latina y el Caribe. Una evaluación sobre la base de 13 países y 71 programas.
[En línea]. Santiago de Chile, CEPAL. 2006b. ISBN 92-1-322860-0. Serie Manuales No 50. Disponible en: http://www.eclac.org/cgi-bin/getProd. asp?xml=/publicaciones/xml/4/26584/P26584. xml\&xsl=/publicaciones/ficha-i.xsl\&base=/publicaciones/top_publicaciones-i.xsl

DI VIRGILIO, María Mercedes, ARQUEROS MEJICA, María Soledad y GUEVARA, Tomás. Veinte años no es nada: procesos de regularización en villas y asentamientos en el Área Metropolitana de Buenos Aires. Ciudad y Territorio: Estudios Territoriales. (167): 109-129, 2011. ISSN 1133-4762.

FERNANDES, Edesio y SMOLKA, Martim. Regularización de la tierra y programas de mejoramiento: nuevas consideraciones. [En línea]. Land Lines. 16(3), julio 2004. ISSN 0279-6503. Disponible en: http://www.lincolninst.edu/pubs/937_ Regularizaci\%C3\%B3n-de-la-tierra-y-programasde-mejoramiento--Nuevas-consideraciones

HERZER, Hilda, DI VIRGILIO, María Mercedes, RODRíGUEZ, Carla y REDOND0, Adriana. ¿Informalidad o informalidades? Hábitat popular e informalidades urbanas en áreas urbanas consolidadas. Pampa: Revista Interuniversitaria de Estudios Territoriales. (4): 85-112, 2008. ISSN 1669-3299.

OSZLAK, Oscar. Merecer la ciudad: los pobres y el derecho al espacio urbano. Buenos Aires, CEDES/ Hvmanitas. 1991. ISBN 950-582-301-0.

OVILLA MANDUJANO, Manuel. Una historia de hoy. La legislación urbana mexicana. En: SOBERANES FERNANDEZ, José Luis, coord. Memoria del III Congreso de Historia del Derecho 
Mexicano. México DF, Universidad Nacional Autónoma de México. 1984. p. 473-488. ISBN 968-837-258-7.

SOTO, Hernando de, GHERSI, Enrique y GHIBELLINI, Mario. El otro sendero: la revolución informal. Lima, Editorial El Barranco. 1986.

SOUZA, Flavio de y ZETTER, Roger. Urban land tenure in Brazil: from centralized state to market processes of housing land delivery. En: ZETTER, Roger, ed. and HAMZA, Mohamed, ed. Market economy and urban change: impacts in the developing world. London, Earthscan. 2004. p. 163-184.

VAPÑARSKY, César y GOROJOVSKY, Néstor. El crecimiento urbano en la Argentina. Buenos Aires, Grupo Editor Latinoamericano-IIED. 1990. 